\title{
14. PHYTOPLANKTON STRATIGRAPHY, DEEP SEA DRILLING PROJECT LEG 20, WESTERN PACIFIC OCEAN ${ }^{1}$
}

\author{
David Bukry, U. S. Geological Survey, La Jolla, California
}

\section{INTRODUCTION}

Leg 20 of the Deep Sea Drilling Project, September to November 1971, in the western Pacific Ocean from Yokohama, Japan, to Suva, Fiji, recovered 57 cores at nine drilling sites (Figure 1). Light-microscope techniques were used to study the coccoliths and silicoflagellates of 75 samples from these cores.

Coccoliths are the most stratigraphically useful fossil group in Leg 20 sediment owing to their common occurrence in most samples and the similarity of their assemblages to those previously zoned in the eastern tropical Pacific (Bukry, 1973). Reworking and overgrowth characterize many of the coccolith assemblages examined. Samples from the shallowest site, DSDP 200, are dominated by foraminifers. Of the nine drilling sites, only DSDP 200 and DSDP 199 yielded biostratigraphically diagnostic material in moderately complete sections.

Systematic paleontology and illustrations of coccoliths from Leg 20 are followed by stratigraphic summaries of the sites and some selected species lists.

\section{SYSTEMATIC PALEONTOLOGY}

\author{
Genus DISCOASTER Tan, 1927 \\ Discoaster blackstockae n. sp. \\ (Plate 1, Figures 1-4)
}

Discoaster brouweri Tan. Takayama, 1969 (in part). [Tokyo] Natl. Sci. Museum Bull., v. 12, p. 447, fig. 5-5.

Description: Discoaster blackstockae, a four-rayed species, has a small oblong central area. The four narrowly tapering, bladelike rays end in simple points. The rays form two large and two small angles. The two small angles are opposite each other and typically are identical at about 60 degrees. Variation from 52 degrees to 62 degrees has been observed for some specimens.

Remarks: Discoaster blackstockae is distinguished from $D$. tamalis by the arrangement of adjacent rays at about 60 or 120 degrees instead of all at 90 degrees, from Discoaster quadramus by its simply terminated rays and nonbirefringence in cross-polarized light in plan view. The angular relation between the rays and the ray morphology suggests that $D$. blackstockae was derived from $D$. brouweri through suppression of one set of rays.

Occurrence: As these four-rayed forms are never common and previously have been considered variants or broken specimens of $D$. pentaradiatus or $D$. brouweri, their full stratigraphic and paleogeographic ranges are not determined. Discoaster blackstockae has been noted most commonly in the Pliocene and latest Miocene of tropical sites from Legs 20, 21, and 23, at Sites DSDP 173, 199, $203,219,225$, and 228 . It may prove to be a useful ecological indicator for tropical assemblages that are dominated by discoasters for preservational reasons, such as strong dissolution.

Size: 8 -20 microns

Holotype: USNM 188509 (Plate 1, Figure 1)

\footnotetext{
${ }^{1}$ Publication authorized by the Director, U. S. Geological Survey.
}

Paratypes: USNM 188510 to 188512

Type locality: Laccadive-Chagos Ridge (DSDP 219-6-5, 110-111 $\mathrm{cm})$.

\author{
Discoaster quadramus n. sp. \\ (Plate 1, Figures 5-6)
}

Discoaster pentaradiatus Tan. Stradner and Papp, 1961 (in part). Österreichische Geol. Bundesanst. Jahrb. Sonderband, v. 17, p. 86 , pl. 21, Fig. 1. Takayama, 1967 (in part). Österreichische Geol. Bundesanst. Jahrb., v. 110, p. 194, pl. 7, fig. 4. Takayama, 1969 (in part). [Tokyo] Natl. Sci. Mus. Bull., v. 12, p. 448, figs 6-4 and 6-6.

Description: Discoaster quadramus, a four-rayed species, has ray-tip bifurcations that are broadly rounded. The rays may make angles of 90 degrees or 60 degrees and 120 degrees. Like Discoaster pentaradiatus, both forms show faint birefringence in crosspolarized light in plan view. The small central area has a faint four-sided knob.

Remarks: Discoaster quadramus is distinguished from D. tamalis and $D$. blackstockae by its bifurcate ray tips or faint cross-polarized light image, from $D$. pentaradiatus by its lack of pentameral symmetry.

Occurrence: This rare species has been reported in the Pliocene of Castell d'Arquato, Italy (Stradner and Papp, 1961; Takayama, 1967), Philippine Sea core V21-98 (Takayama, 1969) and in the Pliocene of the Laccadive-Chagos Ridge (DSDP 219). It is missing in the Pliocene samples of DSDP Leg 20.

Size: $10-20$ microns.

Holotype: USNM 188513 (Plate 1, Figures 5-6). $\mathrm{cm})$.

Type locality: Laccadive-Chagos Ridge (DSDP 219-6-5, 110-111

Genus FASCICULITHUS Bramlette and Sullivan, 1961

Fasciculithus pileatus n. sp.

(Plate 1, Figures 7-9; Plate 2, Figures 1-5)

Discoasteroides megastypus Bramlette and Sullivan. Prins, 1971., Second Plank. Conf. Proc., pl. 6, figs. 12A-C.

Fasciculithus sp. cf. F. ulii Perch-Nielsen. Roth, 1973, Deep Sea Drilling Proj. Initial Repts., v. 17, pl. 16, figs. la-c.

Description: Fasciculithus pileatus is a medium-sized species with smooth straight walls that expand from the base to the apex. Therefore, the body is basically a truncated cone. A large, convex-topped, lens-shaped cap covers the entire top of the body and can extend beyond it. A central stud may connect the cap and body in some specimens. In cross-polarized light, side views have a straight dark line bisecting the body and a straight dark line separating the body and cap, forming three bright areas.

Remarks: Fasciculithus pileatus is unique among other species of the genus owing to its strong-relief three-part division in side view. The only similar species, $F$. ulii, is distinguished by its concave body walls and small flat-topped apex that fails to cap the entire body and gives only weak optical relief in side view. Examination of samples from the type core of $F$. ulii, DSDP 119-25 [not DSDP 119-37 as was indicated in the captions of the type illustrations; Perch-Nielsen, 1971], confirms these distinctions. No wholly and brightly capped Fasciculithus specimens occur in DSDP 119-25-1, $133-134 \mathrm{~cm}$ or DSDP $119-25-2,65-66 \mathrm{~cm}$. $F$. pileatus is distinguished from potential overgrowth forms of $F$. ulii by the cap acting as a single crystalligraphic unit, instead of bilateral units in crosspolarized light. Its long stratigraphic range through the Paleocene is matched only by $F$. tympaniformis, a conservative, parallel-sided, cylindric form with no distinctive ornamentation. 


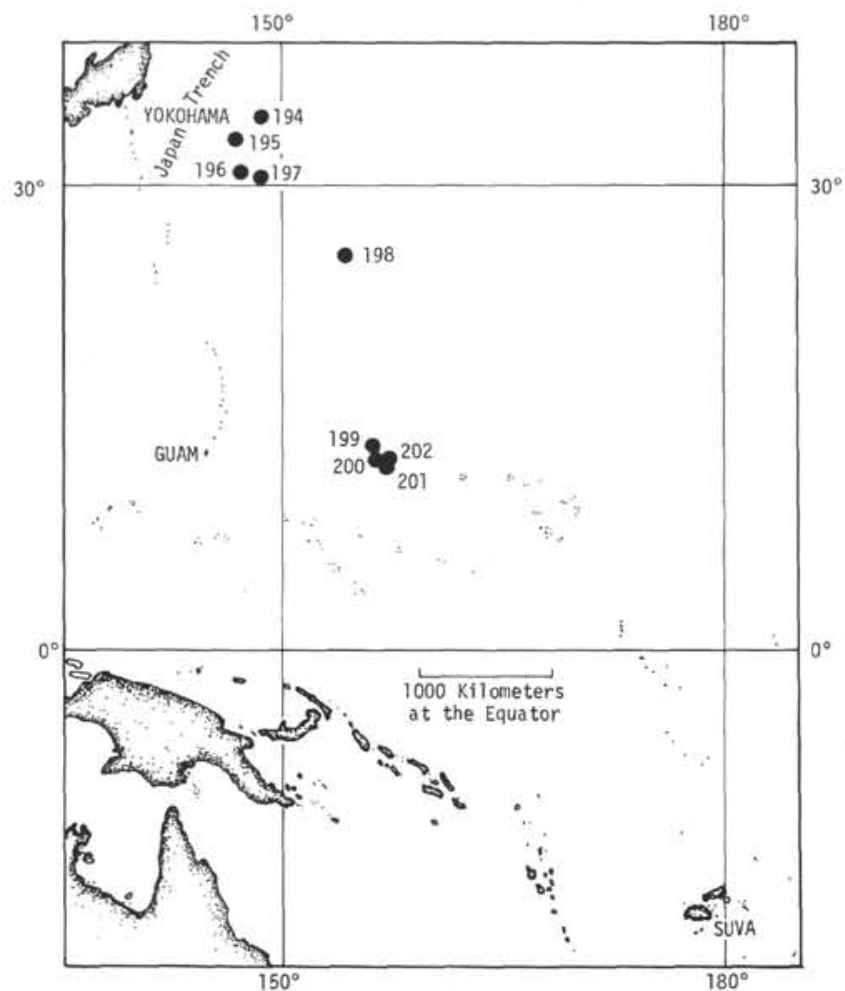

Figure 1. Location of drilling sites of Deep Sea Drilling Project Leg 20, western Pacific Ocean.

Occurrence: Fasciculithus pileatus is presently known from the Paleocene of tropical parts of the Pacific, Indian, Atlantic, and Caribbean. It occurs in DSDP 199-10-2, 34-35 cm; 199-9, CC; and 199-7-1, 76-77 cm, in the Discoaster multiradiatus Zone. It occurs in the Heliolithus kleinpellii Zone in DSDP 144A-3A-3, 114-115 cm and in the Fasciculithus tympaniformis Zone in DSDP 237-50-1, $55-56 \mathrm{~cm} ; 167-39-1,115-116 \mathrm{~cm}$; and 152-7-4, 105-106 cm; and reworked into the middle Eocene of DSDP 171-9-3, 90-91 cm.

Size: 5-12 microns.

Holotype: USNM 188514 (Plate 2, Figures 2-5).

Paratypes: USNM 188515 to 188517 .

Type locality: Caroline Abyssal Plain (DSDP 199-10-2, 34-35 $\mathrm{cm})$.

\section{Genus HAYASTER n. gen.}

Description: Flat discoidal fossils of approximately circular outline modified by straight peripheral edges of several triangularoutlined crystallites composing the disk. Crystallites radiate from a simple center point and are essentially equant. Intercrystallite sutures are simple and straight, although they may be curved on one side of the disk. The disk is nonbirefringent and is dark in cross-polarized light in normal plan view. A small, thin, accessory, central disk, on well-preserved specimens, is birefringent.

Type species: Discoaster perplexus Bramlette and Riedel, 1954. J. Paleontology, v. 28 , p. 400 , pl. 39 , fig. 9.

Remarks: Hayaster is distinguished from superficially similar genera by a combination of characters. Its nonbirefringence in plan view distinguishes it from Braarudosphaera. Its straight peripheral crystallite margins and flat surface distinguish it from Discoaster and Ellipsodiscoaster. Its thickness and closed center distinguish it from Pedinocyclus.

Hayaster perplexus (Bramlette and Riedel) n. comb.

Discoaster perplexus Bramlette and Riedel, 1954. J. Paleontology, v. 28 , p. 400 , pl. 39 , fig. 9 .— Stradner and Papp, 1961. Österreichische Geol. Bundesanst. Jahrb. Sonderband, 17, p. 100, pl. 30, figs. 1-7._Black and Barnes, 1961. J. Roy. Micr. Soc., v. 80 , p. 144 , pl. 24 , fig. 1 .
Boudreaux and Hay, 1969. Rev. Espanola Micropaleont., v. 1, p. 286, pl. 9, figs. 14-18. Bukry, 1971. Deep Sea Drilling Proj. Initial Repts., v. 6, p. 995, pl. 4, fig. 5.

Remarks: Thickly overgrown specimens of Hayaster perplexus show more thickening along the medial axis of the crystallites than along the sutures. In well-preserved specimens, a small central disk, first observed by Black and Barnes (1961), can be seen in light microscopy at high magnification and crosspolarized light because it is heliolithid and birefringent (Boudreaux and Hay, 1967). Because of its thinness and small diameter, less than a third of the main disk, it is not apparent at low magnification.

Occurrence: Hayaster perplexus is most prominent in tropical oceanic assemblages. Stratigraphically it ranges from earliest Miocene through Pleistocene. Sediment sections containing prominent $H$. perplexus occur at DSDP 62,98, and 199 .

\section{Genus HELICOPONTOSPHAERA Hay and Mohler, 1967}

Helicopontosphaera euphratis (Haq) n. comb.

Helicosphaera euphratis Haq, 1966. Stockholm Contrib. Geol., v. 15 , no. 3 , p. 33 , pl. 2 , figs. 1 and 3 .

Helicosphaera parallela Bramlette and Wilcoxon, 1967. Tulane Stud. Geol., v. 5, no. 3, p. 106, pl. 5, figs. 9-10.

Helicopontosphaera recta (Haq) n. comb.

Helicosphaera seminulum recta Haq, 1966. Stockholm Contrib. Geol., v. 15 , no. 3, p. 34 , pl. 2, fig. 6; pl. 3, fig. 4 .

Helicosphaera truncata Bramlette and Wilcoxon, 1967. Tulane Stud. Geol., v. 5 , no. 3, p. 106, pl. 6, figs. 13-14.

\section{Genus TETRALITHUS Gardet, 1955}

Tetralithus praemurus n. sp.

(Plate 2, Figures 6-9)

Description: This compact species has a rounded quadrate to circular outline with no extensions. In cross-polarized light, four equant quadrants are bounded by two S-shaped black suture lines that intersect at the center. Focusing through the various levels in the fossil shows that the curvature of the sutures is more pronounced at one side of the fossil than the other. All four quadrants become black together as the fossil is rotated relative to the direction of cross-polarization.

Remarks: Tetralithus praemurus is distinguished from T. obscurus and $T$. ovalis by its radially symmetric form and equant quadrants, from $T$. pyramidus by its rounded outline and S-shaped sutures, from Micula mura by the more subdued curvature of its sutures and its lack of peripheral extensions.

Tetralithus praemurus, unlike $M$. mura, shows little variation in form. M. mura, as presently constituted, may be a composite taxon. The abbreviated appendages and high relief of the $M$. mura holotype (Martini, 1961) is repeated in later scanning-electromicrograph illustrations of Micula by Clocchiatti (1971). Yet hypotype illustrations by Bramlette and Martini (1964) do not suggest a Micula structure. Single specimens resembling both $M$. decussata at the core and $M$. mura at the periphery occur at DSDP 47.2-13-3 and 199-10-2. Several explanations are possible: (1) Overgrown specimens of slightly evolved Maastrichtian $M$. decussata mimic Tetralithus murus; (2) Micula decussata of the Maastrichtian provides a template that patterns an overgrowth structure that may become separated and independently identified as T. murus of Bramlette and Martini; (3) Micula converges with Tetralithus in the Mastrichtian to form a similar structure. Electronmicroscopy of critical samples will be required to solve the problem.

Occurrence: Tetralithus praemurus occurs in the middle part of the Maastrichtian section of the Shatsky Rise and reworked into the Paleocene of Caroline Abyssal Plain in the western Pacific Ocean. It occurs just below the appearance of $M$. mura.

Size: 5-10 microns.

Holotype: USNM 188518 (Plate 2, Figures 7-9).

Paratype: USNM 188519.

$\mathrm{cm})$. 
TABLE 1

Percentage and Total Count of Sparse Silicoflagellates in Single Smear Slides from DSDP 194

\begin{tabular}{lrr}
\hline & \multicolumn{2}{c}{ Samples } \\
\cline { 2 - 3 } \multicolumn{1}{c}{ Silicoflagellates } & $194-1-2$ & $194-2-1$ \\
\hline Dictyocha aspera & 3 & 19 \\
D. epiodon & 50 & 0 \\
D. fibula & 43 & 52 \\
D. navicula & 0 & 5 \\
Distephanus sp. cf. D. crux & 3 & 0 \\
D. speculum & 0 & 19 \\
Mesocena elliptica & 3 & 5 \\
\cline { 2 - 3 } Total count & 40 & 21 \\
\hline
\end{tabular}

\section{SITE SUMMARIES}

\section{DSDP 194 \\ (lat $35^{\circ} 58.68^{\prime} \mathrm{N}$, long $148^{\circ} 48.64^{\prime} \mathrm{E}$, depth $5754 \mathrm{~m}$ )}

Site DSDP 194 was drilled $630 \mathrm{~km}$ east of the Japan Trench in the abyssal northwestern Pacific to determine the age and composition of regional subbottom acoustic reflectors. Five cores were taken in the 256 meters penetrated. Two samples lacking coccoliths, but containing silicoflagellates, diatoms, and common volcanic ash were examined. Late Quaternary assemblages of the tropical Dictyocha epiodon Zone of silicoflagellates and the Roperia tessellata Zone of diatoms are present in the upper sample, DSDP $194-1-2,73-75 \mathrm{~cm}(39 \mathrm{~m})$. Volcanic ash is more abundant in the lower sample, DSDP 194-2-1, 127-129 cm (142 m), and the siliceous microfossil assemblage is less diagnostic, late Miocene or Pliocene in age. Silicoflagellates are sparse (Table 1); solution-thinned fragments of the diatom Ethmodiscus rex are the most conspicuous siliceous microfossil.

\section{DSDP 195}

\section{(lat $32^{\circ} 46.40^{\prime} \mathrm{N}$, long $146^{\circ} 58.73^{\prime} \mathrm{E}$, depth $5968 \mathrm{~m}$ )}

Site DSDP 195 was drilled approximately $100 \mathrm{~km}$ southwest of DSDP 194 to penetrate the upper opaque acoustic-reflector layer. A sample above this horizon, $195-1-6,75-77 \mathrm{~cm}(71 \mathrm{~m})$, contains volcanic ash and an abundance of solution-thinned silicoflagellate and diatom species indicating a probable Pliocene age. A count of 300 silicoflagellates yields the following percentages: $77 \%$ Dictyocha fibula, 14\% Dictyocha aspera, 5\% Distephanus quinquangellus, $2 \%$ Distephanus speculum, and $<1 \%$ ?Dictyocha hexacantha. The large percentage of Dictyocha relative to Distephanus indicates a tropical depositional environment with a temperature of $27^{\circ} \mathrm{C}$ by the silicoflagellate paleotemperature curve (extrapolated) of Mandra (1969).

All deeper samples available from the site are Early Cretaceous coccolith-rich carbonates of the lower transparent layer, which is similar in age and lithology to the lower transparent layer at DSDP 49 and DSDP 50 on the western flank of Shatsky Rise (Bukry and others, 1971; Douglas and Moullade, 1972).
Diversity is generally low with no pentalithid or nannoconid taxa present. Assemblages from the highest and lowest samples, at 278 meters and 392 meters, are similar, containing Cretarhabdus angustiforatus, Cruciellipsis cuvillieri, Cyclagelosphaera margereli, Diazomatolithus lehmanii, Markalius circumradiatus, Parhabdolithus embergeri, Stephanolithion sp., Watznaueria barnesae, and W. britannica. The ranges of $C$. cuvillieri and $M$. circumradiatus indicate a Valanginian or Hauterivian age (Thierstein, 1971).

\section{DSDP 196 \\ (lat $30^{\circ} 06.97^{\prime} \mathrm{N}$, long $148^{\circ} 34.49^{\prime} \mathrm{E}$, depth $6194 \mathrm{~m}$ )}

Site DSDP 196 was drilled approximately $250 \mathrm{~km}$ southeast of DSDP 195 in a continued attempt to reach basaltic basement below the coccolithic limestone and chert of the lower transparent layer. Only two samples were available: $196-3-1,139-140 \mathrm{~cm}(198 \mathrm{~m})$, and 196-4, CC $(301-310 \mathrm{~m})$. Both contain poor assemblages dominated by Watznaueria barnesae and by fine calcareous debris indicating moderate to strong diagenetic effects. The few specimens of Cretarhabdus angustiforatus, Cruciellipsis cuvillieri, Cyclagelosphaera margereli, Lithraphidites carniolensis, and Parhabdolithus embergeri, also present in the samples, suggest an Early Cretaceous (Valanginian or Hauterivian) age similar to DSDP 195. Mesozoic radiolarians are reported from deeper core samples to the bottom of the site at 196-6 (376-377 m).

\section{DSDP 197}

(lat $30^{\circ} 17.44^{\prime} \mathrm{N}$., long $147^{\circ} 40.46^{\prime} \mathrm{E}$., depth $6153 \mathrm{~m}$ )

No samples available; see report of shipboard scientists.

\section{DSDP 198}

(lat $25^{\circ} 49.54^{\prime} \mathrm{N}$, long $154^{\circ} 35.05^{\prime} \mathrm{E}$, depth $5958 \mathrm{~m}$ )

No samples available; see report of shipboard scientists.

\section{DSDP 199}

(lat $13^{\circ} 30.78^{\prime} \mathrm{N}$, long $156^{\circ} 10.34^{\prime} \mathrm{E}$, depth $6100 \mathrm{~m}$ )

Site DSDP 199 was drilled east of Guam on the eastern margin of the Caroline Abyssal Plain. Coccolith assemblages from the 13 cores attempted, range from late Miocene Discoaster quinqueramus Zone in Core 1 at 58 meters to late Campanian Tetralithus trifidus Zone in Core 12 at 438 meters. Volcanic ash, zeolite minerals, and reworked coccoliths characterize most of the samples examined. Coccolith preservation is commonly poor but variable, with mixtures of specimens exhibiting many degrees of etching and overgrowth. Because of abundant reworking and discontinuous coring, biostratigraphic interpretations must be derived largely from first occurrences of youngest species in a given sample. Representative assemblages from selected samples are listed and discussed below:

\section{Upper Miocene \\ (Discoaster quinqueramus Zone, Ceratolithus primus Subzone)}

199-1-2, 34-35 cm (59 m):

Angulolithina arca, Ceratolithus primus [rare], Coccolithus pelagicus, Cyclococcolithina leptopora, C. macintyrei, Dis- 
coaster asymmetricus, $D$. blackstockae, $D$. brouweri, $D$. challengeri, $D$. pentaradiatus, $D$. quinqueramus, D. surculus, D. variabilis, Helicopontosphaera kamptneri, Reticulofenestra pseudoumbilica, Scyphosphaera pulcherrima, Sphenolithus abies, S. neoabies, and Triquetrorhabdulus rugosus. Reworked taxa: Miocene-Catinaster coalitus, Discoaster bellus, D. neohamatus, and D. pseudovariabilis; Eocene or Oligocene-Cyclicargolithus floridanus, Cyclococcolithina formosa, Dictyococcites bisectus, and Reticulofenestra umbilica.

\section{Upper Miocene \\ (Discoaster quinqueramus Zone, Discoaster berggrenii Subzone)}

199-1-5, 5-6 cm (63 m):

Coccolithus pelagicus, Cyclococcolithina leptopora, C. macintyrei, Discoaster asymmetricus, $D$. berggrenii, D. blackstockae, $D$. brouweri, $D$. loeblichii, $D$. pentaradiatus, $D$. surculus, D. variabilis, Helicopontosphaera granulata, $H$. kamptneri, Reticulofenestra pseudoumbilica, Sphenolithus abies, and Triquetrorhabdulus rugosus. Reworked(?) upper Miocene taxa: Discoaster bellus, D. neohamatus, D. perclarus, and D. pseudovariabilis.

Mixing of stratigraphically and preservationally discordant specimens is greatest at the top of Core 1. Discoasters in 199-1-2 range in preservation from specifically indeterminant specimens having dissolved centers and ray tips (preservation stage -4 ) to blocky and irregular overgrown forms (+4). But some specimens are practically pristine, the original camber, taper, and delicate ornamentation being preserved. Stratigraphic assignment of samples from Core 1 is facilitated by the abundant and diverse discoaster assemblages that can be identified. Key to the assignment in 196-1-2 is the occurrence of Discoaster quinqueramus and D. surculus with Ceratolithus primus and Triquetrorhabdulus rugosus. In 199-1-5 the occurrence of Discoaster berggrenii, $D$. quinqueramus, $D$. surculus, and Triquetrorhabdulus rugosus are considered diagnostic of the lower $D$. quinqueramus Zone. The only apparent reworking in this sample is some admixed discoasters characteristic of the zone directly below. Rare and sporadic Discoaster asymmetricus in this core is not considered biostratigraphically significant, as the species has been noted previously as a rare member of other upper Miocene tropical assemblages (Bukry, 1971). Although recorded as D. asymmetricus here, the specimens might be asymmetric mutants of Discoaster bellus, which is common in the core. In any case, the acme of $D$. asymmetricus is middle Pliocene in age, at which time it was associated with Ceratolithus rugosus, which would be preserved in this tropical deposit if it were Pliocene.

Coccoliths are rare in the ash-rich sediment of Cores 2 and 3 ; assemblages have been severely restricted by etching to stage -4 . A few resistant placolith rims and discoasters, some centerless, compose the trace assemblages. The sediment is probably upper Miocene down to 199-3-5, $35-36 \mathrm{~cm}(82 \mathrm{~m})$, on the basis of the sporadic occurrence of Discoaster sp. cf. $D$. bellus, $D$. berggrenii, $D$. braarudii, $D$. sp. cf. $D$. neohamatus, $D$. pseudovariabilis, and $D$. variabilis. Placoliths are relatively common only near the bottom of Core 3.

\section{Middle Miocene}

\author{
(Discoaster exilis Zone, \\ Discoaster kugleri Subzone)
}

199-3-5, 35-36 cm (82 m):

Coccolithus miopelagicus, $C$. pelagicus, Cyclococcolithina macintyrei, Discoaster braarudii, D. exilis, D. kugleri s. s., D. moorei, D. variabilis, Helicopontosphaera granulata, Reticulofenestra pseudoumbilica, Sphenolithus neoabies, and Triquetrorhabdulus rugosus.

Core 4 contains poorly representative assemblages of middle Miocene age. In 199-4-3, 35-36 cm ( $89 \mathrm{~m})$, six-rayed discoasters resembling $D$. exilis or $D$. variabilis occur, but thick irregular overgrowths $(+4)$ prevent any definite identifications. Associated placoliths such as Coccolithus miopelagicus, C. pelagicus, and Reticulofenestra pseudoumbilica are more moderately overgrown (+2). In 199-4-4, $34-35 \mathrm{~cm}(90 \mathrm{~m})$, preservation is mixed with both etched and overgrown discoasters and placoliths. The assemblage is dominated by open and closed forms of Reticulofenestra pseudoumbilica. The rare occurrences of Cyclococcolithina macintyrei s.a., Discoaster deflandrei, and Sphenolithus heteromorphus indicate a middle Miocene age for Core 4 . Core 5 is largely barren of coccoliths. Rare specimens are recorded only in 199-5-3, 34-35 cm (146 m), where etched Coccolithus miopelagicus, C. pelagicus, Cyclicargolithus floridanus, overgrown Discoaster sp. cf. D. deflandrei, $D$. sp. cf. D. variabilis, Sphenolithus moriformis, and Triquetrorhabdulus carinatus suggest an early Miocene age. Assemblages are more common and diverse in Core $6(200-210 \mathrm{~m})$ owing to admixture by reworking. Species present indicate erosion of Upper Cretaceous and middle or upper Eocene deposits. The host assemblage is probably upper Oligocene or lower Miocene on the basis of the presence of Discoaster calculosus, D. sp. cf. D. variabilis, Helicopontosphaera intermedia, Sphenolithus belemnos, and S. conicus. Eocene taxa include Chiasmolithus grandis, Discoaster barbadiensis, and Triquetrorhabdulus inversus; Cretaceous taxa include Arkhangelskiella cymbiformis, Cribrosphaera ehrenbergii, Prediscosphaera cretacea, and Watznaueria barnesae.

Samples available from Cores 7 to $9(286-314 \mathrm{~m})$ contain upper Paleocene assemblages and reworked Cretaceous. Diagnostic Paleocene species include Chiasmolithus bidens, C. californicus, C. consuetus, Discoaster mohleri, $D$. multiradiatus, D. nobilis, Discoasteroides megastypus, Fasciculithus tympaniformis, and Toweius craticulus. Reworked Cretaceous species include Broinsonia parca, Cretarhabdus crenulatus, Micula mura, Prediscosphaera cretacea, and Watznaueria barnesae. Most specimens are moderately overgrown, and fine calcareous debris is common in the samples.

The upper part of Core 10, down through Sample DSDP $199-10-2,34-35 \mathrm{~cm}(372 \mathrm{~m})$, is assigned to the Discoaster multiradiatus Zone of the upper Paleocene, as is the overlying interval of Cores 7 to 9 . But a lower sample at $199-10-2,112-113 \mathrm{~cm}(373 \mathrm{~m})$, contains lower Paleocene species in a mixed assemblage that is predominantly Upper Cretaceous. This sample represents an early Paleocene deposit, probably near the Cretaceous-Tertiary boundary. Mixing within the Cretaceous assemblage is demonstrated 
by the discordant association of Micula mura of the upper Maastrichtian with Broinsonia parca and Tetralithus trifidus of the Campanian or lower Maastrichtian. Other Cretaceous species include Arkhangelskiella cymbiformis, Cylindralithus gallicus, Cretarhabdus schizobrachiatus, Eiffellithus turriseiffeli, and Prediscosphaera cretacea. Early Tertiary species include Coccolithus sp. [small] and $C$. pelagicus.

Late Cretaceous coccoliths are diverse and abundant in Cores $11(400-409 \mathrm{~m})$ and $12(438-447 \mathrm{~m})$, although diagenesis has produced moderate overgrowth and etching. Core 11 is late Maastrichtian on the basis of Micula mura and the associated assemblage. Core 12 is late Campanian or early Maastrichtian on the basis of Cylindralithus gallicus, Lucianorhabdus cayeuxi, Tetralithus trifidus, and the associated assemblage.

\section{DSDP 200}

(lat $12^{\circ} 50.20^{\prime} \mathrm{N}$, long. $156^{\circ} 46.96^{\prime} \mathrm{E}$, depth $1479 \mathrm{~m}$ )

Site DSDP 200 was drilled on Ita Maitai Seamount in order to investigate the stratigraphy of its 150-meter sediment section. A total of 114 meters of early Eocene to Quaternary foraminiferal sand was drilled before mechanical difficulties forced discontinuation of the drilling. Tropical coccolith assemblages are diverse and abundant. Species in representative samples are listed below.

\section{Pleistocene or Holocene \\ (?Emiliania huxleyi Zone)}

200-1-1, bottom (2 m):

Ceratolithus cristatus [large], Cyclococcolithina leptopora, Emiliania annula, ?E. huxleyi, Gephyrocapsa oceanica, Helicopontosphaera kamptneri, $H$. wallichii, Pontosphaera discopora, Rhabdosphaera stylifera [common], Scyphosphaera sp. cf. S. pulcherrima, Syracosphaera sp., and Thoracosphaera saxea.

\section{Pleistocene \\ (Lower Gephyrocapsa oceanica Zone)}

\section{0-1-5, bottom ( $8 \mathrm{~m})$ :}

Ceratolithus cristatus, Cyclococcolithina leptopora, Emiliania annula, E. ovata, Gephyrocapsa caribbeanica, $G$. oceanica, Hayaster perplexus, Helicopontosphaera kamptneri [abundant], Oolithotus antillarum, Pontosphaera discopora, Rhabdosphaera clavigera, R. stylifera, Syracosphaera sp., and Thoracosphaera saxea [common]. ?Reworked taxa: Cyclococcolithina macintyrei [rare], and Scyphosphaera pulcherrima [rare].

\section{Pleistocene and Pliocene mixed}

200-2-1, bottom (11 m):

Ceratolithus rugosus, Cyclococcolithina leptopora, C. macintyrei, Discoaster brouweri, D. pentaradiatus, D. tamalis, D. triradiatus, Discolithina japonica, Emiliania annula [small, common], Gephyrocapsa oceanica [rare], Hayaster perplexus, Helicopontosphaera kamptneri, Rhabdosphaera stylifera, Scyphosphaera pulcherrima, Syracosphaera sp. [common], and Thoracosphaera saxea.
Upper Pliocene

(Discoaster brouweri Zone, Discoaster pentaradiatus Subzone)

200-2-2, bottom (12 m):

Ceratolithus rugosus, Coccolithus pelagicus, Cyclococcolithina macintyrei, Discoaster asymmetricus, D. brouweri, $D$. pentaradiatus, D. surculus, D. triradiatus, Discolithina sp. cf. D. japonica, Emiliania sp. cf. E. annula, Hayaster perplexus, Helicopontosphaera kamptneri, $H$. sellii, Oolithotus antillarum, Rhabdosphaera clavigera, Scyphosphaera pulcherrima, Syracosphaera sp., and Thoracosphaera saxea.

Upper Pliocene

(Discoaster brouweri Zone, Discoaster tamilis Subzone)

200-3-1, bottom $(21 \mathrm{~m})$ :

Ceratolithus rugosus, Coccolithus pelagicus, Cyclococcolithina leptopora, C. macintyrei, Discoaster asymmetricus, $D$. brouweri, $D$. sp. cf. D. challengeri, $D$. sp. cf. D. decorus, $D$. pentaradiatus, D. surculus, D. tamalis, D. triradiatus, Emiliania sp. cf. E. annula [small], and Scyphosphaera globulata.

Lower Pliocene

(Reticulofenestra pseudoumbilica Zone, Discoaster asymmetricus Subzone)

200-3-2, bottom (22 m):

Ceratolithus rugosus, Cyclococcolithina leptopora, C. macintyrei, Discoaster asymmetricus, D. brouweri [abundant], D. challengeri, D. pentaradiatus, D. tamalis [common], Helicopontosphaera kamptneri, H. sellii [small], Reticulofenestra pseudoumbilica, Scyphosphaera globulata [common], S. recurvata, Sphenolithus abies, $S$. neoabies, and Thoracosphaera saxea.

\section{Lower Pliocene \\ (Ceratolithus tricorniculatus Zone, Ceratolithus rugosus Subzone)}

200-4-1, bottom (30 m):

Angulolithina arca, Ceratolithus bizzarus, C. primus, C. rugosus, Coccolithus pelagicus, Cyclococcolithina leptopora [abundant], Discoaster asymmetricus, D. blackstockae, D. brouweri, D. pentaradiatus, D. surculus, Reticulofenestra pseudoumbilica, and Scyphosphaera globulata. Taxa whose absence is unusual: Helicopontosphaera kamptneri, and Sphenolithus abies.

\section{Mixed Oligocene to Pliocene, probably upper Miocene}

200-5-1, bottom (39 m):

Angulolithina arca, Ceratolithus cristatus, C. primus, C. rugosus, C. sp. cf. C. tricorniculatus, Coccolithus pelagicus, Cyclicargolithus floridanus [rare], Cyclococcolithina leptopora, $C$. macintyrei, Discoaster asymmetricus, $D$. bellus, $D$. blackstockae, D. brouweri, D. challengeri, D. neohamatus, D. pentaradiatus, D. sp. cf. D. quinqueramus, D. surculus, D. tamalis [rare], Discolithina japonica, Helicopontosphaera granulata, H. kamptneri, Reticulofenestra pseudoumbilica, Scyphosphaera globulata, S. sp. cf. S. intermedia, 
S. pulcherrima, Sphenolithus abies, S. neoabies [abundant], $S$. predistentus [rare], and Thoracosphaera saxea.

Middle Miocene (upper Discoaster hamatus Zone)

200-6-1, bottom (49 m):

Catinaster calyculus, C. coalitus, Coccolithus pelagicus, Cyclococcolithina macintyrei, Discoaster bellus, D. braarudii, $D$. challengeri s. s., $D$. sp. cf. $D$. challengeri [overgrown, resembles $D$. extentus] $D$. hamatus, $D$. neohamatus, D. prepentaradiatus, Discolithina sp. [large, imperforate], Hayaster perplexus, Helicopontosphaera kamptneri, Reticulofenestra pseudoumbilica, Sphenolithus neoabies, and Triquetrorhabdulus rugosus.

200-7, CC (57-67 m):

Catinaster calyculus, Coccolithus pelagicus, Discoaster asymmetricus, $D$. bellus, $D$. braarudii, $D$. challengeri s. s., $D$. sp. cf. $D$. challengeri, $D$. hamatus, $D$. neohamatus, $D$. prepentaradiatus, Discolithina sp. [large, imperforate], Hayaster perplexus, Helicopontosphaera kamptneri, Reticulofenestra pseudoumbilica, Scyphosphaera pulcherrima, Sphenolithus neoabies, Thoracosphaera saxea, and Triquetrorhabdulus rugosus.

\section{Middle Miocene \\ (lower Sphenolithus heteromorphus Zone)}

200-9-1, bottom (87 m):

Coccolithus miopelagicus, Cyclicargolithus floridanus, Cyclococcolithina macintyrei, Discoaster sp. cf. D. deflandrei, D. sp. cf. D. exilis, Discolithina sp. [large, imperforate], Helicopontosphaera granulata, H. kamptneri, and Sphenolithus heteromorphus.

200-9-3, bottom (90 m):

Coccolithus miopelagicus, C. pelagicus, Coronocyclus sp., Cyclicargolithus floridanus [abundant], Cyclococcolithina macintyrei, Discoaster sp. cf. D. deflandrei [abundant, irregular overgrowth +4], D. sp. cf. $D$. exilis [abundant, irregular overgrowth +4], Discolithina sp. [large, imperforate], Helicopontosphaera granulata, Scyphosphaera recurvata, and Sphenolithus heteromorphus.

Lower Miocene

(Helicopontosphaera ampliaperta Zone)

200-9-6, bottom (95 m):

Braarudosphaera sp. cf. B. bigelowi [rare], Coccolithus miopelagicus, C. pelagicus, Coronocyclus sp., Cyclicargolithus floridanus [abundant], Discoaster deflandrei s.a. [abundant], Discolithina sp. cf. D. segmenta, D. sp. [large, imperforate], Hayaster perplexus [rare, less overgrown than discoasters], Helicopontosphaera granulata, Sphenolithus heteromorphus [common; long apical spines], and Thoracosphaera $\mathrm{sp}$.

Lower Miocene

(Sphenolithus belemnos Zone)

200-10, CC (105-114 m):

Coccolithus miopelagicus, C. pelagicus, Coronocyclus sp., Cyclicargolithus sp., Discoaster deflandrei, D. druggii [rare], Helicopontosphaera euphratis, H. granulata, $H$. intermedia, Sphenolithus belemnos, $S$. conicus, $S$. dissimilis, $S$. moriformis, and Triquetrorhabdulus carinatus.

\section{Lower Eocene}

200A-2A, CC (123-132 m):

Campylosphaera dela, C. eodela, Chiasmolithus consuetus, C. eograndis, Coccolithus pelagicus, Cyclococcolithina formosa, Discoaster barbadiensis, D. sp. cf. D. lodoensis, Discoasteroides kuepperi, Lophodolithus sp. cf. L. mochlophorus, L. nascens, L. sp. cf. L. rotundus, Sphenolithus radians, and Syracosphaera fimbriata.

\section{DSDP 201}

(lat $12^{\circ} 49.89^{\prime} \mathrm{N}$, long. $156^{\circ} 44.59^{\prime} \mathrm{E}$, depth $1564 \mathrm{~m}$ )

No cores cut.

\section{DSDP 202}

(lat $12^{\circ} 48.90^{\prime} \mathrm{N}$, long. $156^{\circ} 57.15^{\prime} \mathrm{E}$, depth $1515 \mathrm{~m}$ )

Site DSDP 202 was drilled about 20 kilometers south of DSDP 200 at the eastern edge of Ita Maitai Seamount. Mixed-age coccolith assemblages are present in the two coccolith-bearing samples available. An Eocene suite of species in Core 2 is unusual in the absence of Reticulofenestra umbilica, because the remainder of the Eocene species suggest the upper middle Eocene, where $R$. umbilica is typically common.

Lower Pliocene

(Reticulofenestra pseudoumbilica Zone, Discoaster asymmetricus Subzone)

202-1, CC (49-59 m):

Ceratolithus rugosus [common], Coccolithus pelagicus, Cyclococcolithina macintyrei, Discoaster asymmetricus, $D$. brouweri [abundant], D. challengeri [abundant], $D$. pentaradiatus, D. surculus, D. tamalis, Helicopontosphaera kamptneri, H. sellii [rare], Oolithotus antillarum, Reticulofenestra pseudoumbilica [common], Scyphosphaera globulata, and Sphenolithus neoabies. In-hole, slumped Pleistocene taxa: Ceratolithus cristatus, Gephyrocapsa oceanica, and $G$. omega.

Upper Oligocene or lower Miocene mixed with middle Eocene

202-2, CC (65-74 m):

Middle Eocene taxa. Campylosphaera dela, Chiasmolithus grandis, Coccolithus eopelagicus, Cyclococcolithina formosa, C. protoannula Cyclicargolithus floridanus, Dictyococcites scrippsae, Discoaster barbadiensis [rare], D. nodifer [rare], D. saipanensis [rare], Helicopontosphaera reticulata, Sphenolithus furcatolithoides, S. obtusus, and Thoracosphaera prolata.

Upper Oligocene or lower Miocene. Coccolithus miopelagicus, Cyclicargolithus abisectus, C. floridanus, Dictyococcites bisectus, D. scrippsae, Discoaster deflandrei [common], Helicopontosphaera intermedia, Sphenolithus dissimilis, $S$. moriformis, and Triquetrorhabdulus carinatus.

\section{REFERENCES}

Black, M. and Barnes, B., 1961. Coccoliths and discoasters from the floor of the South Atlantic Ocean: Roy. Micr. Soc. J., v. 80 , p. 137. 
Boudreaux, J. E. and Hay, W. W., 1969. Calcareous nannoplankton and biostratigraphy of the late PliocenePleistocene-Recent sediments in the Submarex cores: Rev. Española Micropaleont., v. 1, p. 249.

Bramlette, M. N. and Riedel, W. R., 1954. Stratigraphic value of discoasters and some other microfossils related to Recent coccolithophores: J. Paleontol., v. 28 , p. 385.

Bramlette, M. N. and Martini, E., 1964. The great change in calcareous nannoplankton fossils between the Maestrichtian and Danian: Micropaleontology, v. 10, p. 291.

Bukry, D., 1971. Coccolith stratigraphy Leg 7, Deep Sea Drilling Project. In Winterer, E. L., Riedel, W. R., et al., Initial Reports of the Deep Sea Drilling Project, Volume VII: Washington (U.S. Government Printing Office), p. 1513 .

1973. Coccolith stratigraphy, eastern Equatorial Pacific, Leg 16 Deep Sea Drilling Project. In van Andel, Tj. H., Heath, G. R., et al., Initial Reports of the Deep Sea Drilling Project, Volume XVI: Washington (U.S. Government Printing Office), p. 653.

Bukry, D., Douglas, R. G., Kling, S. A., and Krashenninikov, V., 1971. Planktonic microfossil biostratigraphy of the northwestern Pacific Ocean. In Fischer, A. G., Heezen, B. C., et al., Initial Reports of the Deep Sea Drilling Project, Volume VI: Washington (U. S. Government Printing Office), p. 1253.
Clocchiatti, M., 1971. Contribution a l'etude du nannoplankton calcaire du Neogene d'Afrique du nord: Mus. Natl. Histoire Nat. Mém. C23, 1.

Douglas, R. G. and Moullade, M., 1972. Age of the basal sediments on the Shatsky Rise, western North Pacific Ocean: Geol. Soc. Am. Bull., v. 83, p. 1163.

Mandra, Y. T., 1969. Silicoflagellates: A new tool for the study of Antarctic Tertiary climates: U.S. Antarctic J., v. 4, p. 172.

Martini, E., 1961. Nannoplankton aus dem Tertiar und der obersten Kreide von SW-Frankreich: Senckenbergiana Lethaea, v. 42 , p. 1.

Perch-Nielsen, K., 1971. Einige neue Coccolithen aus dem Paleozän der Bucht von Biskaya: Geol. Soc. Denmark Bull., v. 20, p. 347.

Stradner, H. and Papp, A., 1961. Tertiäre Discoasterideriden aus Osterreich und deren stratigraphischen Bedeutung mit Hinweisen auf Mexiko, Rumänien und Italien: Österreichische Geol. Bundesanst. Jahrb. Sonderband, v. 7, p. 1 .

Takayama, T., 1969. Discoasters from the Lamont Core V21-98: [Tokyo] Natl. Sci. Mus. Bull., v. 12, p. 431.

Thierstein, H. R., 1971. Tentative Lower Cretaceous calcareous nannoplankton zonation: Eclogae Geol. Helvetiae, v. 64 , p. 459. 


\section{PLATE 1}

Coccolith Photomicrographs, $2000 X$

(BF = Bright-field; $\mathrm{XN}=$ Cross-polarized $)$

(Scale bar equals 5 microns

Figures 1-4 Discoaster blackstockae n. sp.

1. Holotype, USNM 188509, DSDP 71.0-4-5, 63-64 $\mathrm{cm}$; BF.

2. USNM 188510, DSDP 199-1-5, 5-6 cm; BF.

3. USNM 188511, DSDP 72A-3A-5, 63-64 cm; BF, with a specimen of Discoaster triradiatus.

4. USNM 188512, DSDP 219-6-5, 110-111 cm; BF.

Figures 5-6 Discoaster quadramus n. sp.

5. Holotype, USNM 188513, DSDP 219-6-5, 110-111 $\mathrm{cm} ; \mathrm{XN}$.

6. BF.

Figures 7-9 Fasciculithus pileatus n. sp.

7. USNM 188515, DSDP 199-10-2, 34-35 cm; BF, $45^{\circ}$.

8. $\mathrm{XN}, 45^{\circ}$, with specimen of Coccolithus pelagicus s. a.

9. USNM 188516, DSDP 199-10-2, 34-35 cm; BF, $82^{\circ}$. 
PLATE 1
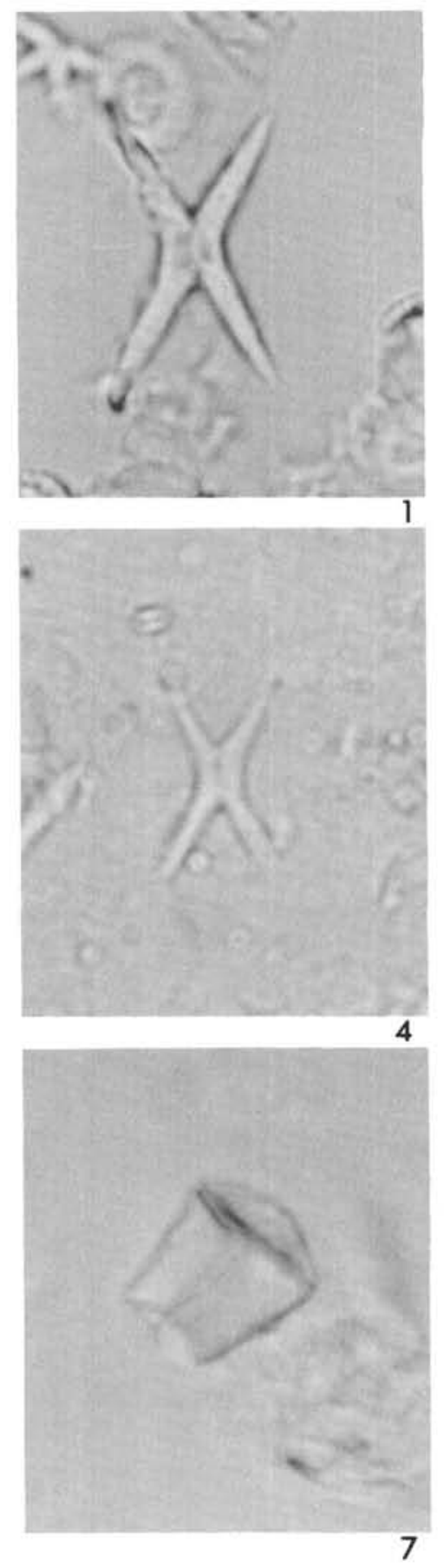
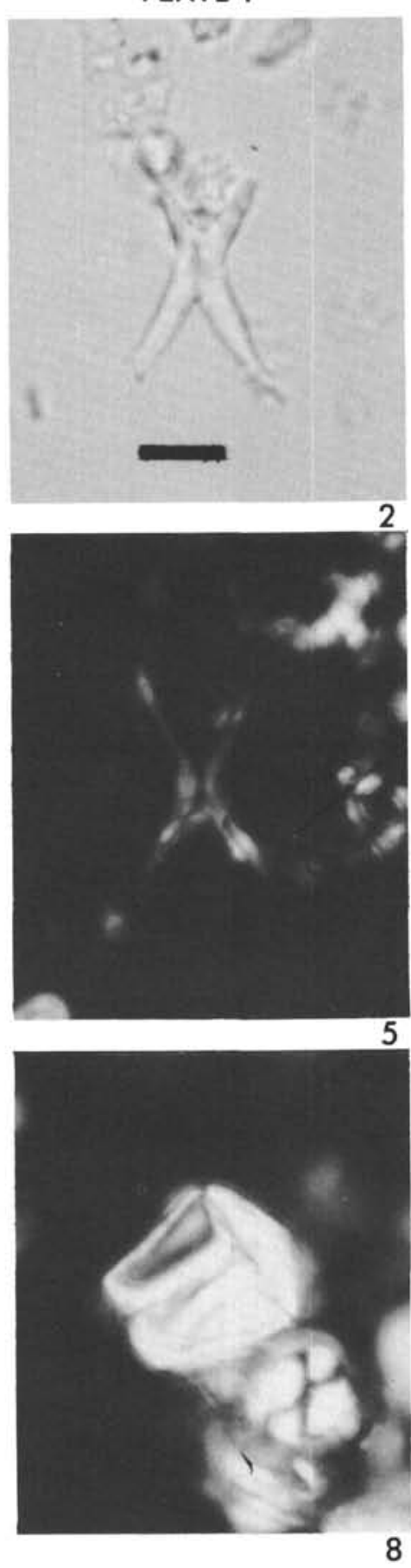
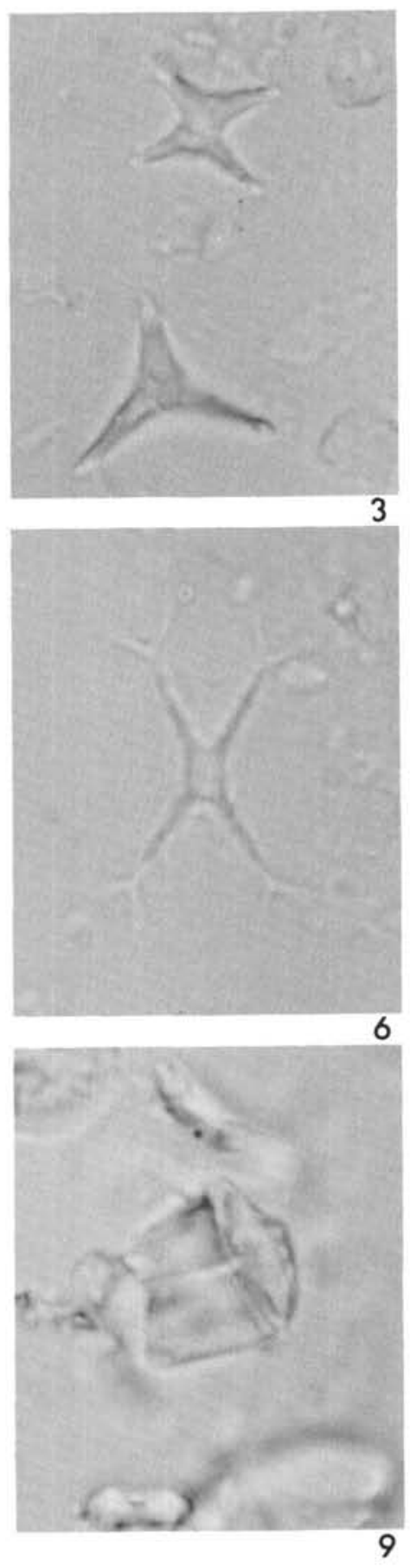


\section{PLATE 2}

Coccolith Photomicrographs, $2000 \times$

$$
\begin{gathered}
(\mathrm{BF}=\text { Bright }- \text { field }, \mathrm{PC}=\text { Phase-contrast } ; \mathrm{XN}=\text { Cross-polarized }) \\
\text { Scale bar equals } 5 \text { microns }
\end{gathered}
$$

Figures 1-5 Fasciculithus pileatus n. sp.

1. USNM 188517, DSDP 199-10-2, 34-35 cm; BF, $45^{\circ}$.

2. Holotype, USNM 188514, DSDP 199-10-2, 34-35 $\mathrm{cm} ; \mathrm{BF}, 0^{\circ}$.

3. $\mathrm{XN}, 45^{\circ}$.

4. $\mathrm{XN}, 25^{\circ}$.

5. $\mathrm{PC}, 45^{\circ}$.

Figures 6-9 Tetralithus praemurus n. sp.

6. USNM 188519, DSDP 47.2-13-3, 80-81 cm; XN.

7. Holotype, USNM 188518, DSDP 199-10-2, 34-35 $\mathrm{cm} ; \mathrm{XN}$ [suture inked for emphasis] .

8. Partial XN.

9. BF. 
Plate 2
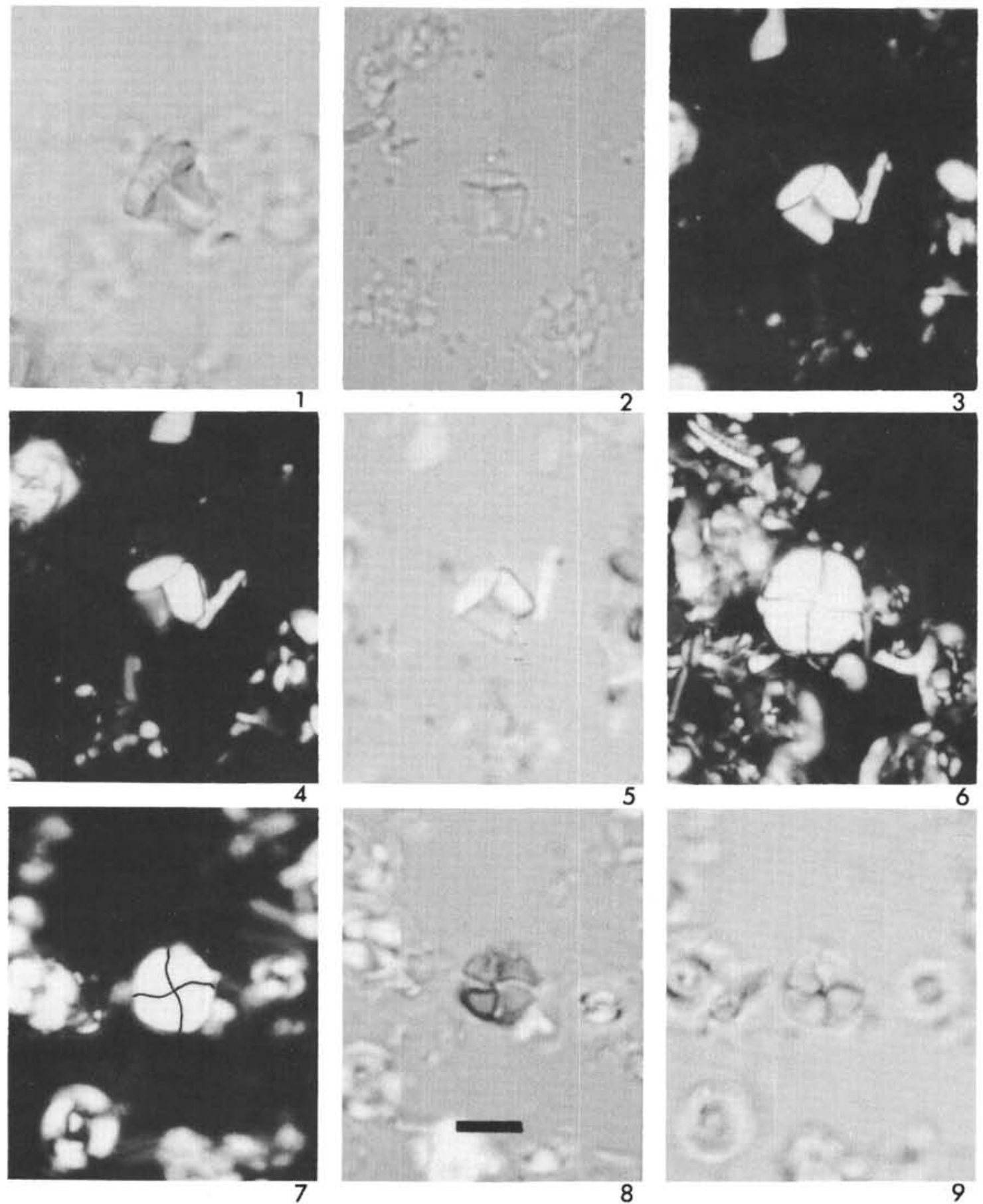